\title{
S-1-4 胸腹部大動脈瘤に対する胸腹部大動脈全置換手術の検討
}

\author{
一適応ならびに術式上の問題点—
}

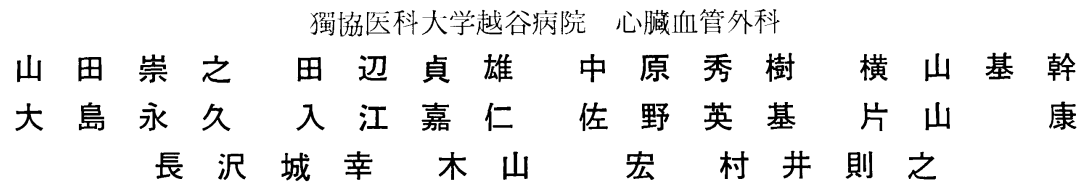

犿因を問わず胸腹部大動脈瘤は手術適応，術式の選択 等問題点が多く, Adamkiewicz 動脈腹部分枝再建の術 式屯確立されたとはいい難い。解離性胸腹部大動脈瘤は 破裂, 内臟虚血により予後が修飾され, 胸腹部大動脈全 置換が最も根治的であるが，手術の危険性も高い。われ われは最も根治的で, 臟器虚血時間が短く, 安全, 確実 に行える術式を臨休例に応用してきた。術式は胸腹部大 動脈再建用グラフトに側枝を付け，部分体外循環下に近 位処理端に再建グラフト, 胸部下行大動脈遠位処理端に 側枝を吻合した後，体外循環を中止し，瘤内灌流を再開 する. 腹部主要分枝は DeBakey 術式によって再建し， Adamkiewicz 動脈は腹部あるいは総腸骨動脈グラフト からの側枝グラフトを上行させ，trimming した瘤壁に 吻合再建する ${ }^{1,2)}$. 自験例から本術式の適応，手技上の問 題点等在検討した。

\section{対 象}

最近 6 年間の胸部大動脈瘤手術症例は, 真性瘤一弓部 大動脈瘤 13 例, 胸部下行大動脈瘤 12 例, 胸腹部大動 脈瘤 2 例，大動脈弁閉鎖不全を伴った上行大動脈瘤 11 例, 解離性-AAE に合併した DeBakey I 型解離 3 例, DeBakey I 型 10 例, DeBakey II 型 2 例, DeBakey III $b$ 型 11 例, 計 61 例であった. そのうち胸腹部大動 脈全置換症例は真性瘤の 2 例, Marfan 症候群で Bentall 手術後 9 年の 1 例，DeBakey III b 型解離の 5 例で施行 された（表 1 ).

\section{術式}

解離性胸腹部大動脈瘤では部分体外循環下に近位，遠 位端の解離腔閉鎖後，近位に再建グラフトの近位端を吻

本稿は第 22 回日本心臟血管外科学会学術総会「シンポジゥ 厶 S-1 大動脈瘤に対する昖大再建術」(1992 年 4 月，仙 台）において発表した。

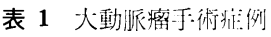

(1985 1992)

\begin{tabular}{|c|c|c|}
\hline 真性瘤 & & 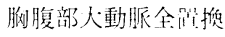 \\
\hline 弓部大動挀瘤 & 13 例 & \\
\hline 胸部下行大動脈瘤 & 12 例 & \\
\hline 胸腹部大動脈瘤 & 2 例 & 2 例 \\
\hline Annuloaortic ectasia & 8 例 & \\
\hline \multicolumn{3}{|l|}{ 解離性大動脈瘤 } \\
\hline AAE+DeBakey I 型 & 3 例 & 1 例 \\
\hline DeBakey I 型 & 10 例 & \\
\hline DeBakey II型 & 2 例 & \\
\hline DeBakey III b型 & 11 例 & 5 例 \\
\hline 計 & 61 例 & 8 例 \\
\hline
\end{tabular}

合，側枝人工血管を遠位端に吻合し体外循環を中止す る.胸部下行大動脈近位に吻合可能な大動脈壁が存在す る真性瘤, 人工血管置換術後の DeBakey III b 型解離例 では体外循環を用いず，胸部下行大動脈の部分遮断下に 再建グラフトを端側吻合する.

胸腹部大動脈再建グラフトを Y-graft で延長し，末梢 に吻合し雨下肢への血流を再開する.腹部大動脈分枝の 再建は DeBakey 術式 ${ }^{3)}$ に準じて行った. Bentall 手術瑷 9 年で弓部, 胸腹部大動脈合併例では偏平胸郭之癒着の ために trap door incision によらなければ上行置換グラ フトに到達できない例も経験した．この例では第 4 肋間 開胸の trap door incision を行い, 弓部大動脈置換, そ して胸腹部大動脈全置換を第 7 肋問開胸を追加して spiral incision ${ }^{4)}$ で行った（図 1 ). Adamkiewicz 動脈再建 は経時的変遷をみたが，胸腹部大動脈再建グラフトから の側枝と直接端端吻合 3 例, 胸腹部大動脈再建グラフト と並行に走るグラフトと側側吻合 4 例, 腹腔動脈直上で 腹部大動脈結禁，瘤空置で再建せずの 1 例の各方法を用 いた（図 2 ).

\section{手 術適応}

解離性大動脈瘤 : DeBakey I 型では, Marfan 症候群 

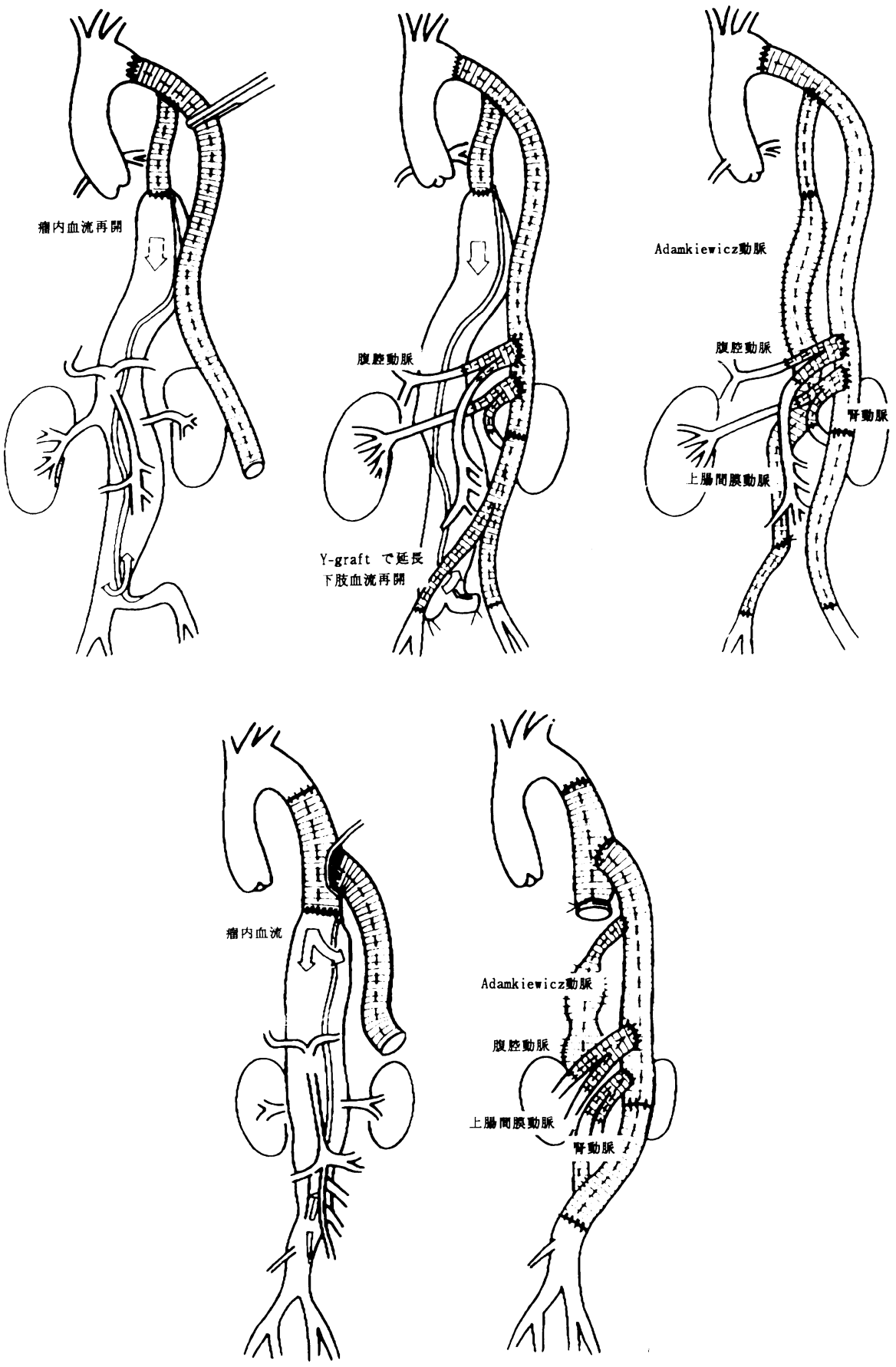

図 1 胸腹部大動脈置換術式 

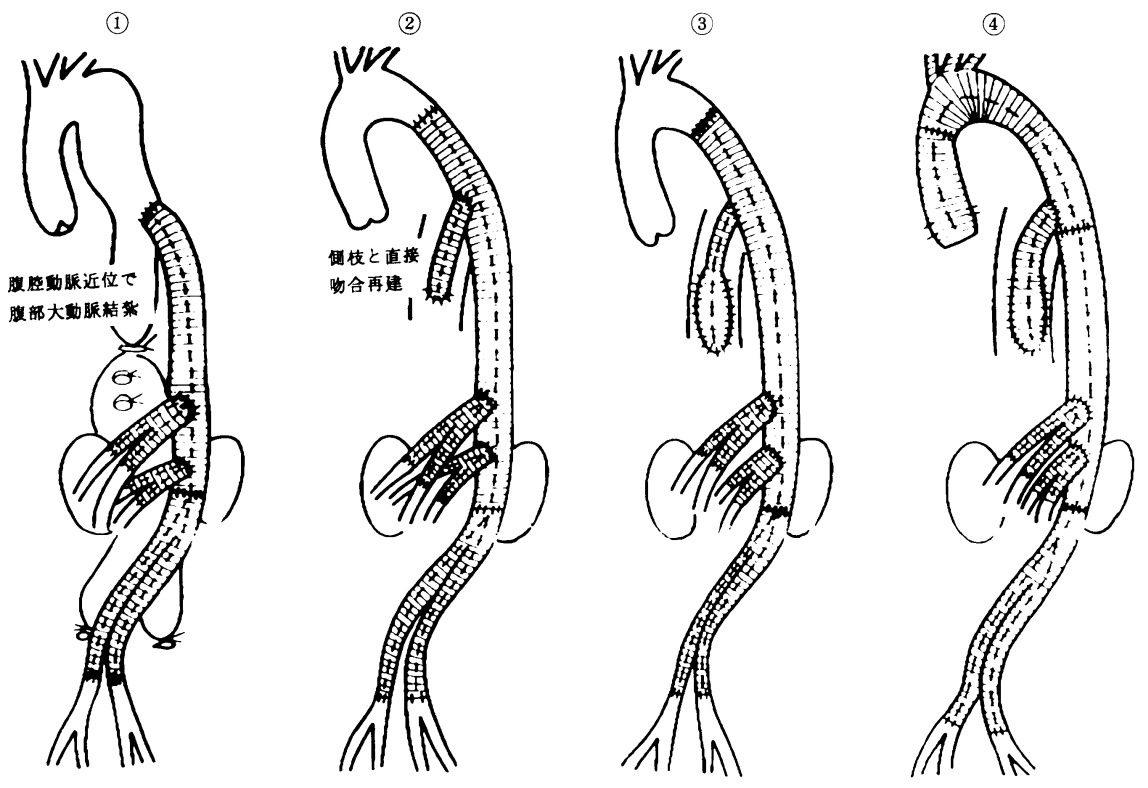

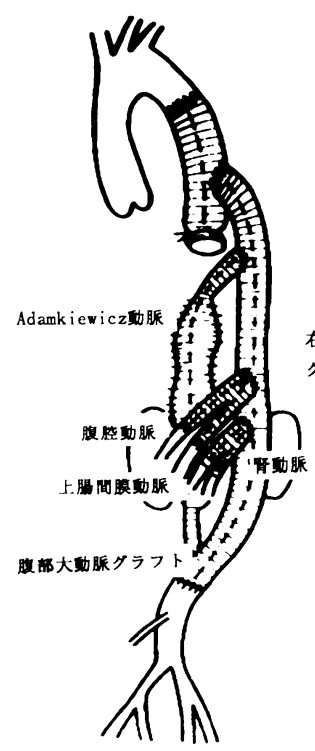

(5)

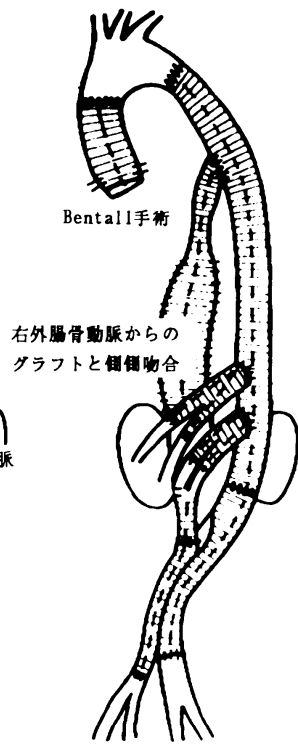

(6)

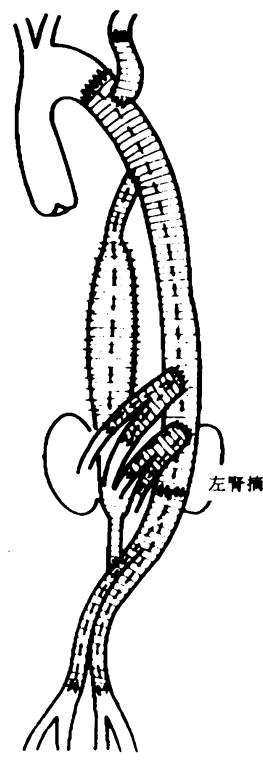

(7)

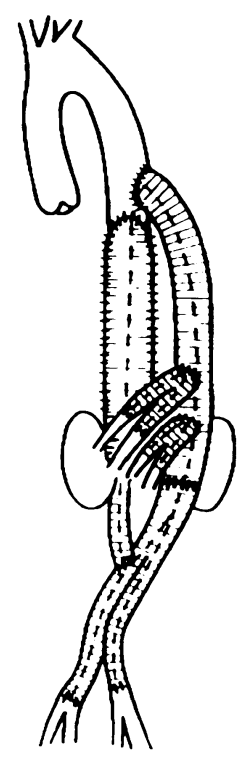

(8)

図 2 Adamkiewicz 動脈再建術式

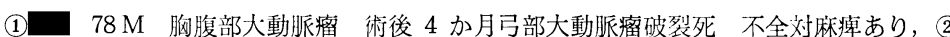

DeBakey III b 型 術後 5 年健 なし, 3 $48 \mathrm{M}$ DeBakey III b 型解離 右下肢虚血 MNMS 右総腸骨動脈解離腔灌流， (4) $27 \mathrm{M}$ Bentall 術後 9 年弓部，胸腹部一期的全罳換 術後 5 日 肺出血 急性腎不全，(5) $46 \mathrm{M}$ DeBakey III b 型 術後 3 年健 なし，6 37F DeBakey III b 型 術後 2 年健 なし, (7) $60 \mathrm{M}$ DeBakey III b 型 急性腎不全 下肢虚血 腋窩動脈-大 腿動脈バイパス, 8 $66 \mathrm{M}$ 慢性㹂不全, 透析患者 胸腹部大動脈㢞 高 $\mathrm{K}$ 血症, 不整脈 
表 2 手術適応

\begin{tabular}{|c|c|c|c|c|}
\hline & & 手術適応 & $\mathrm{CT}$, 造影所見 & その他 \\
\hline \multicolumn{5}{|c|}{ 解離性大動脈瘤 } \\
\hline \multirow[t]{4}{*}{1.} & $27 \mathrm{M}$ & DeBakey I 型 & 两側睯動脈 & Marfan 症侯群 \\
\hline & & 弓部, 胸腹部解離性大動脈瘤 & 腹腔動脈 & Bentall 術後 9 年 \\
\hline & & 切迫破裂, 巨大瘤 & 上腸間膜動脈 & \\
\hline & & & 解離腔起始 & \\
\hline \multirow[t]{2}{*}{2.} & $30 \mathrm{~F}$ & DeBakey III b 型 & & Marfan 症候群 \\
\hline & & 切迫破裂, 巨大瘤 & & \\
\hline \multirow[t]{2}{*}{3.} & $46 \mathrm{M}$ & DeBakey III b 型 & 左腎動脈 & \\
\hline & & 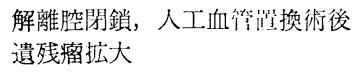 & 解離腔起始 & \\
\hline \multirow[t]{3}{*}{4.} & $37 \mathrm{~F}$ & DeBakey III b 型 & & \\
\hline & & 切迫破裂, 巨大瘤 & & Marfan 症候群 \\
\hline & & & & Bentall 手術後 2 年 \\
\hline \multirow[t]{2}{*}{5.} & $48 \mathrm{M}$ & DeBakey III b 型 & & \\
\hline & & 切迫破裂 巨大瘤 & $\begin{array}{l}\text { 左䀠動脈 } \\
\text { 解離腔起始 }\end{array}$ & \\
\hline \multirow[t]{3}{*}{6.} & $60 \mathrm{M}$ & 下肢血行障害 & 两側腎動脈 & 腋窩動脈-大腿動㷧 \\
\hline & & 虛血性腎不全 & 解離腔起始 & バイパス術 \\
\hline & & & & 下肢血行障害 \\
\hline \multicolumn{5}{|c|}{ 真性胸腹部大動脈瞃 } \\
\hline 7. & $78 \mathrm{M}$ & 破裂 & & \\
\hline 8. & $66 \mathrm{M}$ & 切迫破裂 & & $\begin{array}{l}\text { 慢性肾不全 } \\
\text { 血液透析 }\end{array}$ \\
\hline
\end{tabular}

で AAE のために Bentall 手術が 9 年前に施行され, 上行置換以遠の解離腔遺残が巨大瘤化した切迫破裂例で は腎動脈, 腹腔動脈, 上腸間膜動脈が解離腔起始であっ た. DeBakey III b 解離では Marfan 症候群で左上肺野 の巨大瘤形成例, 解離腔閉鎖, 人工血管置換術後遺残解 離腔の拡大をみ, 左腎動脈が解離腔起始の症例, Marfan 症候群で Bentall 術後 2 年の瘤切迫破裂例, 巨大瘤を 形成し, 解離腔によって著しく真腔が圧迫され, 左腎動 脈解離腔起始の症例, 下肢血行障害がみられ, 両側の腋 窝一大腿動脈バイパスを必要とし虚血性腎不全に陥った 症例の 5 例であった。真性瘤では腹部大動脈破裂で緊急 手術を余儀なくされ, 開腹のみでは処理しえなかった胸 腹部大動脈瘤例, そして, 慢性腎不全で血液透析下にあ
り, 破裂の疑いで緊急外科治療を要した例の 2 例, 計 8 例であった（表 2 ).

\section{成 績}

胸腹部大動脈全置換 8 例中 4 例 $(50 \%)$ の生存であっ た. 手術死亡の原因は症例 1 Bentall 術後 9 年で弓部, 胸腹部大動脈瘤拡大が著しく, 一期的に弓部, 胸腹部大 動脈人工血管置換を施行した 1 例では術後 5 日目, 肺出 血, 急性腎不全で死亡した. 症例 2 右総腸骨動脈が解離 腔加灌流され, 左外腸骨動脈真腔加の送血の部分体 外循環下の置換施行例では，灌流中，右下肢虚血による 循環障害で術中より右下肢の虚血性変化, 硬直, 色調变 化等を見術後 MNM 症候群による死亡1例，症例 6

表 3 手術成績（死亡例）

\begin{tabular}{|c|c|c|c|}
\hline \multirow[t]{3}{*}{1.} & $27 \mathrm{M}$ & DeBakey I 型解離 & \\
\hline & & Bentall 術後 9 年. & 術後 5 日 \\
\hline & & 弓部, 胸腹部大動脈一斯的全览換 & 肺出血，㷛性肾不全 \\
\hline \multirow[t]{2}{*}{2.} & $48 \mathrm{M}$ & DeBakey III b 型解離 & \\
\hline & & 右総腸骨動脈解離挖灌流 & $\begin{array}{l}\text { 術後 } 2 \text { 日 } \\
\text { 右下肢虚血，MNM 旋候群 }\end{array}$ \\
\hline \multirow[t]{2}{*}{3.} & $60 \mathrm{M}$ & DeBakey III b 型解離 & \\
\hline & & $\begin{array}{l}\text { 下肢虚血, 腋窩動脈-大腿動脈バイパス } \\
\text { 虚血性督不全, 左腎摘 }\end{array}$ & $\begin{array}{l}\text { 術後 } 4 \text { 日 } \\
\text { 急性腎否全. }\end{array}$ \\
\hline \multirow[t]{2}{*}{4.} & $66 \mathrm{M}$ & 慢性透析患者 䏫腹部大動脈瘤切迫破裂 & 術後1日 \\
\hline & & 糖尿病 & 高K血为，不整脈 \\
\hline
\end{tabular}


表 4 手術成綪（生存例）

\begin{tabular}{|c|c|c|c|c|}
\hline & & 缩 型 & Adamkiewicz 動脈再建術式 & 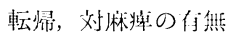 \\
\hline 5. & $30 \mathrm{~F}$ & DeBakey III b 型 & 大動脈グラフトよりの側枝と值接吻合で再建 & 術後 5 年健 \\
\hline 6. & $46 \mathrm{M}$ & DeBakey III b 型 & 大動脈再建グラフトと韭行に走るグラフトと側側吻命 & 術後 3 年健 \\
\hline 7. & $37 \mathrm{~F}$ & DeBakey III b 型 & 右外腸骨動脈グラフトからのグラフトと側側吻合 & 術後 2 作健 \\
\hline \multirow[t]{3}{*}{8.} & $78 \mathrm{M}$ & 胸腹部大動脈瘤 & 腹腔動脈近位で腹部人動脈維紫 & 術後 4 汃月 \\
\hline & & & & 宁部大動脈瘤破裂死 \\
\hline & & & & 不全対麻痺 \\
\hline
\end{tabular}

DeBakey III $b$ 型解離で転送時すでに下肢虚血のために 腋䆚一大腿動脈バイパス術が施行され, 乏尿, 高 BUN, $\mathrm{Cr}$ などの虚血性腎不全, 症例 8 慢性腎不全で透析療法 下にあった切迫破裂例で術後第 1 日，高 $\mathrm{K}^{+}$血症による 不整脈死の 1 例, 計 4 例であった（表 3 ).

生存例での対㾁瘦発生を術式別にみる之, 症例 7 腹腔 動脈直上で腹部大動脈を結禁, 瘤空置し, Adamkiewicz 動脈再建を行扔なった症例では不全対麻痺の発生をみ た．この例では遗残弓部大動脈瘤破裂のために術後 4 か月で死亡した．辰期生存の 3 例では症例 2 Adamkiewicz 動脈を大動脈再建グラフトからの側枝によって直 接再建した例, 症例 3 DeBakey III b 型の解離腔閉鎖, 人工血管置換施行後に末梢胸部下行大動脈解離による遗 残腔が拡大し瘤状となった例，症例 $4 \mathrm{AAE}$ のために Bentall 術後 2 年で胸部下行大動脈に解離を認め, 拡大 する胸部陰影をみた例等いずれも対麻瘦をみず, 術後 5 年, 3 年, 2 年で健在である (表 4 ).

\section{考察}

胸腹部大動脈瘤の外科治療には多くの問題点があり, 術式屯確立されていない，腹部主要分枝再建を伴う広範 囲胸腹部大動脈置換は根治的な術式であるが，侵襲が過 大で手術手技がやや複雑であるために手術適応に関して は慎重でなりればならない，解離性大動脈瘤におりる解 離様式はさまざまであり，腹部分枝の解離腔起始を持つ 症例では, 胸部下行大動脈における解離腔閉鎖, 人工血 管置換のみでは解離腔の血栓閉塞によって対麻痺の発 生, 遺残瘤の拡大, 臟器虚血がみられる場合, そして, 真性胸腹部大動脈瘤破裂では腹部大動脈分枝, Adamkiewicz 動脈の完全再建のみが救命的な意義を持つものと 考えられる.われわれら胸腹部大動脈全置換に際して, 腹部分枝，Adamkiewicz 動脈再建の虚血時間短縮を図 る術式を考案し臨床例に応用してきだ ${ }^{1,2)}$ が，今回の胸 腹部大動脈全置換症例は何れもこの範疇に属するもので ある。

胸腹部大動脈全置換術式は，全胸腹部大動脈への到達
法, 真腔あるいは解離腔起始の腹部分枝の再建方法, 低 位肋阔動脈, 高位腰動脈など Adamkiewicz 動脈再建法 と対麻疾の予防, 大動脈遮断中の臟器虚血の予防, 補助 手段の選択等が問題点として挙げられている ${ }^{5)}$. 到達経 路としては Stoney $ら^{4)}$ の spiral opening 法を用い，胸 部下行大動脈, 腹部大動脈分枝の良好な視野が得られた。 胸部下行大動脈起始の解離性大動脈瘤では問題はなかっ たが，症例 $1 の$ Bentall 術後 9 年で弓部，胸腹部大動 脈瘤合併例では偏平胸郭之瘾着のために胸骨正中切開で は上行大動脈への到達，遮断が困難であった．第 4 肋間 開胸による trap door incision を行い，弓部大動脈を 置換した後, 胸腹部大動脈置換を第 7 肋間開胸の spiral incision で行った.

腹部主要分枝の再建は全例 DeBakey 術式在用いた。 部分体外循環あるいは遠心ポンプによる左房脱血，大腿 動脈送血を用いて近位端の処理終了後瘤内血流を再開 し，虚血時間の短縮を図る手法を 5 例に用いた，真性瘤 やDeBakey III b 型の解離腔閉鎖人工血管置換術後で胸 部下行大動脈に吻合可能な大動脈，または人工血管があ る場合は体外循環非使用下に大動脈壁，あるいは置換人 工血管の部分遮断によって，近位吻合を完了し，この後 腹部大動脈雨建の方法を 3 例で行った。腹部主要分枝, 特に, 腹腔動脈, 上腸間膜動脈は近接して起始してい るととが多いので起始部大動脈壁を部分遮断下にカフ状 に切除し，人工血管側壁に吻合する Crawford 術式も可 能である.しかしながら，これらの動脈が解離腔，真腔 両者から分枝の場合はこの方法では手技が複雑となり， 困難な場合むみられる，多くの場合，乙れらの動脈は十 分な太さを有しており，腸管虚血を考元ると別個に吻合 再建することが望ましい。

腎動脈は spiral opening 法では左右著しく離れた位 置にあり，別個に再建する方法しかない，また，腎動脈 が太くなく，大動脈壁をカフ状に切除し吻合口を大きく する必要に迫られる，瘤内灌流に用いた側枝の遮断に よって瘤内压を減少させると大きくカフ状にくり抜くこ とができる. 


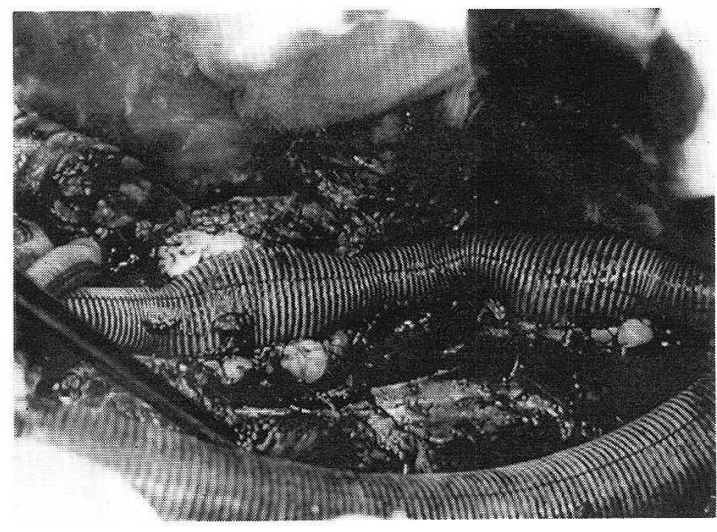

図 3 分節们 Adamkiewicz 動脈再建

Crawford 術式は腹部大動脤分枝露出の必要がなく, 吻合箈所が少ない再建血管の屈曲, 閉寨が少ない等が DeBakey 術式に勝るとされている5). 欠点としては血流 再開までの藏器虚血がみられ，術中重要墸器の虚血防止 対策が必要であることである。こ机に対して DeBakey 術式では術野に臟器虚血防止の複雑な回路がなく, 虚血 時間は吻合に要する時間のみで，各動脈の吻合再建は 10 分前後で可能である. 馏壁から力フ状に切除するて とによって吻合もきわめて容易となる。

脊髄の血流確保のためには Adamkiewicz 動脈再建は 重要である.この動脈は T 8 L 2 間に約 $80 \%$ が存在 するとされる，真性瘤では汾状硬化による閉塞，あるい は血栓によって被覆され術中見いだすことが困難な場合 が多い，また，見いだされても同定確認することは不可 能であるとされる.SEP モニターの有無にかかわらず T 8〜 L 2 間のすべての肋間動脈，腰動脈を再建するこ とが最屯確実な方法であると考えられる。初期には長期 生存の 1 例で, Adamkiewicz 動脈之考えられる動脈を 胸腹部大動脈再建グラフトからの個枝によって再建し対 麻㾌の発生をみなかったが，確実な方法とは考元られな い.

最近の症例では腹部大動脈再建グラフトまたは総腸骨 動脈グラフトからの上行する側枝グラフトをつけ後面を 縦切し、トリミングした瘤壁に吻合し再建す万方法をと ったままた，遮断可能な瘤の場合は分節的に行ったほう が虚血時間の短縮になる（図 3 ). 大動脈再建グラフト の近位から並行に走り, Adamkiewicz 動脈再建後, 再 び大動脈グラフトに吻合して競合による閉塞も考えられ たが，遠隔期においても閉塞がみられていない，最む確 実な力法は, 症例 4 で行ったように総腸骨動脈グラフト から上行するグラフトで再建し，腹部大動脈分岐部直後
の一方の Y-graft 脚を結紫することによって競合が起 こらないようにしたほうが良いと考えている.

Marfan 症候群においては, 大動脈壁の脆弱性から遗 残解離腔から巨大瘤発生の可能性が高い。DeBakey I 型解離において, Bentall 手術時の解離腔閉鎖のみでは 遗隔期において遺残解離腔の巨大瘤化の危険性が高いの で厳重な追跡が必要である. DeBakey III b 型解離にお いても，巨大瘤の発生をみる例では積極的に拡大手術在 考慮すべきむのと考えている．しかしながら，DeBakey $\mathrm{I}$ 型の Bentall 術後 9 年で広範な弓部, 胸腹部大動脈溜 で一期的に弓部, 胸腹部大動脈置換手術を行った症例で は, 術後 5 日目, 肺出血, 腎不全で死亡したが, 手術侵 襲があまりにも過大であるので，分割的に置換術を行う べきであったと反省している.

残万死亡 3 例は術前, 術中のいずれかに臟器虚血によ る不全を合併した症例であった。1例は解離発症後, 下 肢虚血老併発し腋窩動脈一大腿動脈バイパス手術施行後 転送され，すで虔血性腎不全の併発をみた症例で全置 換時, 梗塞左腎摘出を余儀なくされた。他の症例も慢性 鳌不全のために慢性透析療法下にあった，全置換当日は 高 $\mathrm{K}^{+}$血症あ良好にコントロールされ順調であったが, 術後第 1 日, 透析開始直前に突然の高 $\mathrm{K}^{+}$血症のために 不整脈が出現し心室細動のため急死した，症例 5 は右総 腸骨動脈が解離腔によって灌流され, 体外循環時, 左外 腸骨動脈送血によって右下肢が虚血に陥り MNM 症候 群により，急激な経過をとり死亡した。偽腔灌流は解離 性大動脈瘤ではしばしば経験することであり。術中もこ れらの血流変化老慮した対応が必要である。

術中の出血量は腹部大動脈分枝の広範な露出, 分枝, Adamkiewicz 動脈などの吻合再建数の多いとと, 近位 端処理は体外循環を用いることなどによって子想外に多 量の出血がみられた。部分体外循環を用いた症例では $16,180 \pm 9,908 \mathrm{ml}$ であり, 体外循環非使用例では 6,231 $\pm 1,330 \mathrm{ml}$ で使用例に比し少量であった．したがって， 部分体外循環によって近位端処理が必要な場合は，休外 循環終了後, 十分なへパリンの中和をまって，胸腹部大 動脈全置換を行うほうが, 出血量の節減に有効であると 考えられた，最近の症例では，体外循環使用例でむ出血 量は $6,100 \mathrm{ml}$ であり, 自己血液回収装置の使用によっ て出血量の問題は解決されるものと期待される.

\section{結語}

胸腹部大動脈全置換に際して, 部分体外循環下に近位 端に再建用グラフト，遠位端に側枝を吻合，瘤内血流を 
再開し重要藏器の虚血時間短縮を図った。腹部分枝は DeBakey 術式に準じ, Adamkiewicz 動脈は腹部, 総腸 骨動脈グラフトから上行する側枝グラフトの後面に切開 を加えトリミングした瘤壁に吻合再建する，真性瘤 2 例, 胸腹部解離性大動脈瘤 (DeBakey I 型 1 例, III b 型 5 例）計 8 例で 4 例の生存を得た，死亡例は術前，術 中の虚血性臟器不全合併 3 例, 一期的马部, 胸腹部大動 脈全置換の手術侵襲過大の 1 例, 計 4 例であった，重要 臓器の虚血時間はきわめて短く, 長期生存例では腹部臓 器不全, 対麻痺の発生をみていない。
文献

1）山且崇之, 田辺貞雄, 横山基幹ほか：胸腹部解離性大動挀 瘤の外科治療一虚血時間の短綰並びに Adamkiewicz 動脈 を含む完全血行再建老目指す術式. 日胸外会誌 37 : 20092015, 1989.

2) 山田崇之, 四辺貞雄, 入江嘉仁ほか：胸腹部大動脈におけ る低位肋間，高位腰動脈並びに Adamkiewicz 動脈再建術 式. 胸部外科 43: 942-952, 1990 .

3) DeBakey, M.E., Henly, W.S., Cooley, D. A. et al. : Surgical management of dissecting aneurysms of the aorta. J. Thorac. Cardiovasc. Surg. 49 : 130-149, 1965.

4) Stoney, R. J. and Wylie, E. J. : Surgical management of arterial lesions of the thoracoabdominal aorta. Am. J. Surg. 126 : 152-164, 1973.

5）数井暉久, 山田 修, 伊藤敏行ほか：胸腹部解襍性大動脈 瘤の切迫破裂例飞対する胸腹部大動脈全渞換術。日胸外会 誌 37 : 1436-1440, 1989 . 